\title{
Efficiency of shallow- and deep-water trawling in the Mediterranean and its implications for discard reduction
}

\author{
Dario Pinello ${ }^{1,2}$, Jennifer Gee ${ }^{3}$, Paolo Accadia ${ }^{1}$, Evelina Carmen Sabatella ${ }^{1}$, Sergio Vitale ${ }^{4}$, \\ Kostantinos Polymeros ${ }^{2}$, Fabio Fiorentino ${ }^{4}$ \\ ${ }^{1}$ NISEA-Fisheries and Aquaculture Economic Research, Via Irno 11, 84135 Salerno, Italy. \\ (DP) (Corresponding author) E-mail: pinello@ nisea.eu. ORCID-iD: http://orcid.org/0000-0001-5777-6764 \\ (PA) E-mail: accadia @ nisea.eu. ORCID-iD: http://orcid.org/0000-0003-3832-3377 \\ (ECS) E-mail: e.sabatella@nisea.eu. ORCID-iD: http://orcid.org/0000-0002-2129-1869 \\ ${ }^{2}$ Department of Ichthyology and Aquatic Environment, School of Agricultural Sciences, University of Thessaly, Fytoko \\ Street, 38445 Nea Ionia, Magnesia, Greece. \\ (KP) E-mail: polikos@uth.gr. ORCID-iD: http://orcid.org/0000-0001-7092-0425 \\ ${ }^{3}$ Food and Agriculture Organization of the United Nations, Statistics and Information Branch, Fisheries and Aquaculture \\ Department, Rome, Italy. \\ (JG) E-mail: jennifer.gee @ fao.org. ORCID-iD: http://orcid.org/0000-0002-3690-9510 \\ ${ }^{4}$ CNR-Istituto per l'Ambiente Marino Costiero, Sede di Mazara del Vallo, V. L. Vaccara 61, 91026 Mazara del Vallo (TP), \\ Italy. \\ (SV) E-mail: sergio.vitale@cnr.it. ORCID-iD: http://orcid.org/0000-0001-6063-4126 \\ (FF) E-mail: fabio.fiorentino@iamc.cnr.it. ORCID-iD: http://orcid.org/0000-0002-6302-649X
}

\begin{abstract}
Summary: The Mazara del Vallo fleet is one of the main fleets of large trawlers in the Mediterranean. Traditionally, the two main fishing strategies adopted by the fleet can be summarized as follows: pesca a fresco $(<250 \mathrm{~m})$, mainly targeting fish and cephalopods sold fresh; and pesca a congelato $(>250 \mathrm{~m})$, mainly targeting deep-water shrimp sold frozen. The second fishing strategy has become increasingly important over the last decade. This paper aims to investigate the extent to which the choice of targeting deep-water shrimp impacted the level of technical and scale efficiency for the fleet assessed through an input-oriented data envelopment analysis. The analysis was based on data collected under the Italian National Programme within the European Data Collection Framework, as well as through a focus group discussion with the trawler skippers. The results showed that the pesca a congelato trawlers had the highest average efficiency, with both technical and scale efficiency close to the maximum level. On the basis of information collected during the focus group discussion on the pesca a congelato strategy, technical efficiency was coupled with a lower discard rate and the widespread use of LED lights. The findings were discussed in light of the objective of discard reduction in European fisheries, one of the pillars of the reformed common fishery policy.
\end{abstract}

Keywords: data envelopment analysis; technical and scale efficiency; fishery strategy; bottom trawling; focus group discussion; fishing lights; discard reduction.

Comparación de la eficiencia de las flotas de arrastre costera y de profundidad en el Mediterráneo y sus implicaciones para la reducción de los descartes

Resumen: La flota de Mazara del Vallo es una de las principales flotas de grandes arrastreros en el Mediterráneo. Tradicionalmente, las dos estrategias de pesca adoptadas por la flota pueden resumirse en pesca a fresco $(<250 \mathrm{~m})$, cuyas especies objetivo son peces y cefalópodos comercializados frescos y pesca a congelato $(>250 \mathrm{~m})$ que tiene por objetivo gambas de profundidad que se venden congeladas. Esta segunda estrategia ha llegado a ser más importante en la última década. En esta contribución investigamos hasta qué punto la opción de pescar gambas de profundidad tiene impacto sobre los niveles de eficiencia técnica y de escala para la flota, evaluados mediante el Análisis de Envoltorio de Datos determinado por insumos. Para el análisis nos basamos en datos recolectados a través del programa nacional italiano del marco europeo de recogida de datos, además de discusión con un grupo focal de patrones de embarcaciones de arrastre. Los resultados muestran que los arrastreros que practican la pesca a congelato tienen la eficiencia media más alta, con la eficiencia técnica y de escala cercana al nivel máximo. En base a la información recogida durante la discusión con el grupo focal sobre la estrategia de pesca a congelato, la eficiencia técnica está correlacionada con una tasa de descarte inferior y con el uso generalizado de dispositivos LED. Se discuten los resultados en el marco del objetivo de reducción de descartes de las pesquerías europeas, uno de los pilares de la reforma actual de la política pesquera común.

Palabras clave: análisis de envoltorio de datos; eficiencia técnica y de escala; estrategia de pesca; arrastre de fondo; discusión en grupo focal; luces de pesca; reducción de descartes. 
Citation/Como citar este artículo: Pinello D., Gee J., Accadia P., Sabatella E.C., Vitale S., Polymeros K., Fiorentino F. 2018. Efficiency of shallow- and deep-water trawling in the Mediterranean and its implications for discard reduction. Sci. Mar. 82S1: 97-106. https://doi.org/10.3989/scimar.04749.22A

Editor: F. Maynou.

Received: January 8, 2018. Accepted: May 17, 2018. Published: July 2, 2018

Copyright: (C) 2018 CSIC. This is an open-access article distributed under the terms of the Creative Commons Attribution 4.0 International (CC BY 4.0) License.

\section{INTRODUCTION}

Efficiency, together with sustainable utilization and equity in access to resources, is seen as one of the main aspects to be considered in the management of fisheries (Cochrane 2000). According to Grafton et al. (2006), efficiency in fisheries is considered to be doing the best possible with the available resources in terms of fish stock and fishing inputs. To measure firm-level efficiency, one technique that can be applied is data envelopment analysis (DEA), which was first introduced in the literature in 1957 (Farrell) for application in the public sector and then in agriculture. It was then expanded on and further developed until today, when it has become a fundamental tool for efficiency analysis in fisheries. The technique extracts information about the production process of each vessel [herein called a decision making unit (DMU)] through linear calculations used to construct a non-parametric piece-wise frontier of the data. Efficiency measures for each DMU are then calculated relative to this frontier. Each DMU's performance measure traces out a best-practice frontier (Coelli et al. 2005), so all DMUs lie either on or below the frontier, and this is how performance, in the form of efficiency, is tracked. Technical efficiency (TE) and scale efficiency (SE) are measures of efficiency calculated using DEA. According to Farrell (1957) and Kumbhakar and Lovell (2000), TE measures the relationship between a vessel's inputs to the fishing process and its outputs. Full efficiency is achieved when outputs are maximized from a given set of inputs. By contrast, technical inefficiency can result from a fishing strategy with inputs, such as energy, labour or other running costs, that are too high or a fishing strategy that has excessive invested capital in relation to the potential revenue. Reasons for inefficiency have been associated with shifts in management (e.g. Pascoe et al. 2001), vessel characteristics (e.g. Pascoe and Coglan 2002) and skipper characteristics (e.g. Squires and Kirkley 1999, Tingley et al. 2005, Vázquez-Rowe and Tyedmers 2013). According to Grafton et al. (2006) SE expresses whether a firm is operating at its "optimal" size so that any modifications to its size will render the unit less efficient, and it is measured by dividing the aggregate efficiency by the TE of each DMU. In the literature, TE has been generally estimated through an output-oriented approach (e.g. Kirkley et al. 2002, Reid et al. 2003, Vestergaard et al. 2003, Kirkley et al. 2004). In the studies found in the literature, an outputorientation has been generally used to investigate the factors affecting the TE of fishing vessels under a quota system (e.g. Tingley et al. 2005). In the Mediterranean, an application of output-oriented DEA was found in Maravelias and Tsitsika (2008), who assessed the efficiency in purse-seine fishing in the eastern Mediterranean. Another example of estimating TE by applying DEA in small-scale fisheries in the Mediterranean was provided by Idda et al. (2009). Both of these studies used variations of output-oriented approaches. Few studies in fisheries have utilized an input-oriented approach, even in the Mediterranean where fisheries are largely managed under input control systems. However, the application of input-oriented DEA has been considered particularly meaningful for fisheries managed under an input control system (e.g. Pinello et al. 2016).

Input-oriented DEA models have also been applied to estimate input-based measures of overcapacity, where overcapacity is synonymous with overcapitalization (Ward et al. 2004): usually, when fishing vessels are not technically efficient it is because they have running costs that are too high and they are operating in a state of overcapacity in the sense that a lower capacity could be used to achieve the same harvest. A fleet in a status of overcapacity is characterized by low TE and is then not properly using its input in order to produce outputs. The link between overcapacity and efficiency of fishing fleets has been investigated by Pascoe et al. (2003), Grafton et al. (2006) and Maravelias and Tsitsika (2008). Overcapacity has been a key issue in the EU fleets, with most of the fisheries in a status of inefficiency and in most cases heavily subsidized, as was highlighted by Villasante (2010), Villasante and Sumaila (2010) and Maravelias and Tsitsika (2008). In the Mediterranean Sea, the overfishing of most of the fishery resources and the overcapacity of fleet have been clearly diagnosed (Colloca et al. 2013, 2017). To better balance the equilibrium between the stock status and the fleet capacity, the European Commission has adopted programmes for reducing the fleet capacity. Since 2002, this reduction programme has placed particular emphasis on monitoring fleet exit and entrances (EU 2371/2002) and supported the scrapping of fishing vessels (EU No 508/2014). This has led to a consistent decrease in the Italian fleet in terms of gross tonnage and engine power, which has particularly impacted the Mazara del Vallo fleet in Sicily. This fleet is composed of distant-water trawlers, mainly operating in the Strait of Sicily, one of the most important fishing area of the Mediterranean, with many demersal stocks-including deep-water shrimp-shared between European and third countries (Fiorentino et al. 2008, Gristina et al. 2006, Knittweiss et al. 2013). Shared stocks require a particularly effective management strategy, as their 
management is outside the responsibility of the individual states and consequently of the General Fisheries Commission for the Mediterranean, and the European Commission are undertaking several common actions to enforce rational management and improve utilization of these marine resources. Therefore, a broad analysis of the fleets exploiting shared stocks, including the efficiency component, is critical for effective management to be exercised.

To contribute to this process, this paper aims to investigate the efficiency of the strategies employed by the Mazara del Vallo fleet: pesca a fresco, trawling mainly in shallow-water and pesca a congelato, mainly targeting deep-water shrimp. The analysis was made through an input-oriented DEA comparing TE and SE performance. Differences in efficiency were found between the different fishing strategies, and these are discussed in light of the use of LED lights, along with the implications for discard reductions.

\section{MATERIALS AND METHODS}

\section{The fishing strategies}

The fleet of Mazara del Vallo is almost exclusively trawlers, and it is one of the largest fleets of trawlers found in one port across the Mediterranean. The large vessels, most of which are longer than $24 \mathrm{~m}$ LOA, particularly differentiate this fleet from the other Mediterranean fleets. This concentration of large vessels is the result of the vessels' ability to fish in many distant grounds around the Mediterranean. They have been traditionally employed on long fishing trips (1525 days) within both national and international waters around the Strait of Sicily and the Sardinian Channel (GSA 12-16) and the eastern Mediterranean (GSA 2125) (Fig. 1). The fleet operates in waters up to a depth of $800 \mathrm{~m}$.

The fishing strategy of Mazara del Vallo trawlers can be divided into two broad categories. The first strategy, pesca a fresco (Di Stefano 1989), focuses on species caught in shallow to mid-waters $(<250 \mathrm{~m})$, which are sold as a fresh product. The main target species are red mullets (Mullus spp.); sparids (Dentex spp., Pagrus spp. and Pagellus spp.); cephalopods (Octopus vulgaris, Sepia officinalis, Loligo vulgaris, Illex coindetii and Eledone spp.); rays (Raja spp.); caramote prawn (Penaeus kerathurus); scorpionfish (Scorpaena spp.); monkfish (Lophius spp.); European hake ( $M$. merluccius); and deepwater rose shrimps (Parapenaeus longirostris [DPS]). The second strategy, pesca a congelato (Di Stefano 1989), with landings sold frozen, targets different groups of species at two different depth ranges: DPS and Norway lobster at depths of 250 to $400 \mathrm{~m}$ and giant red shrimp (Aristaemorpha foliacea [ARS]) and blue and red shrimp (Aristeus antennatus [ARA]) at depths greater than $400 \mathrm{~m}$ (Dimech et al. 2012, Knittweiss et al. 2013, Fiorentino et al. 2013). Traditionally, trawlers have operated using a mix of the two fishing activities, even in the course of one day, with pesca a congelato conducted during the daytime and pesca a fresco during the night-time.

Due to the EU scrapping policy and voluntary departures, the trawl fleet of vessels from Mazara del Vallo measuring $24 \mathrm{~m}$ and above was reduced from 137 vessels in 2004 to 85 in 2016. This corresponded to a $38 \%$ decrease in terms of number of vessels and a $35 \%$ decrease in $\mathrm{kW}$ (Table 1).

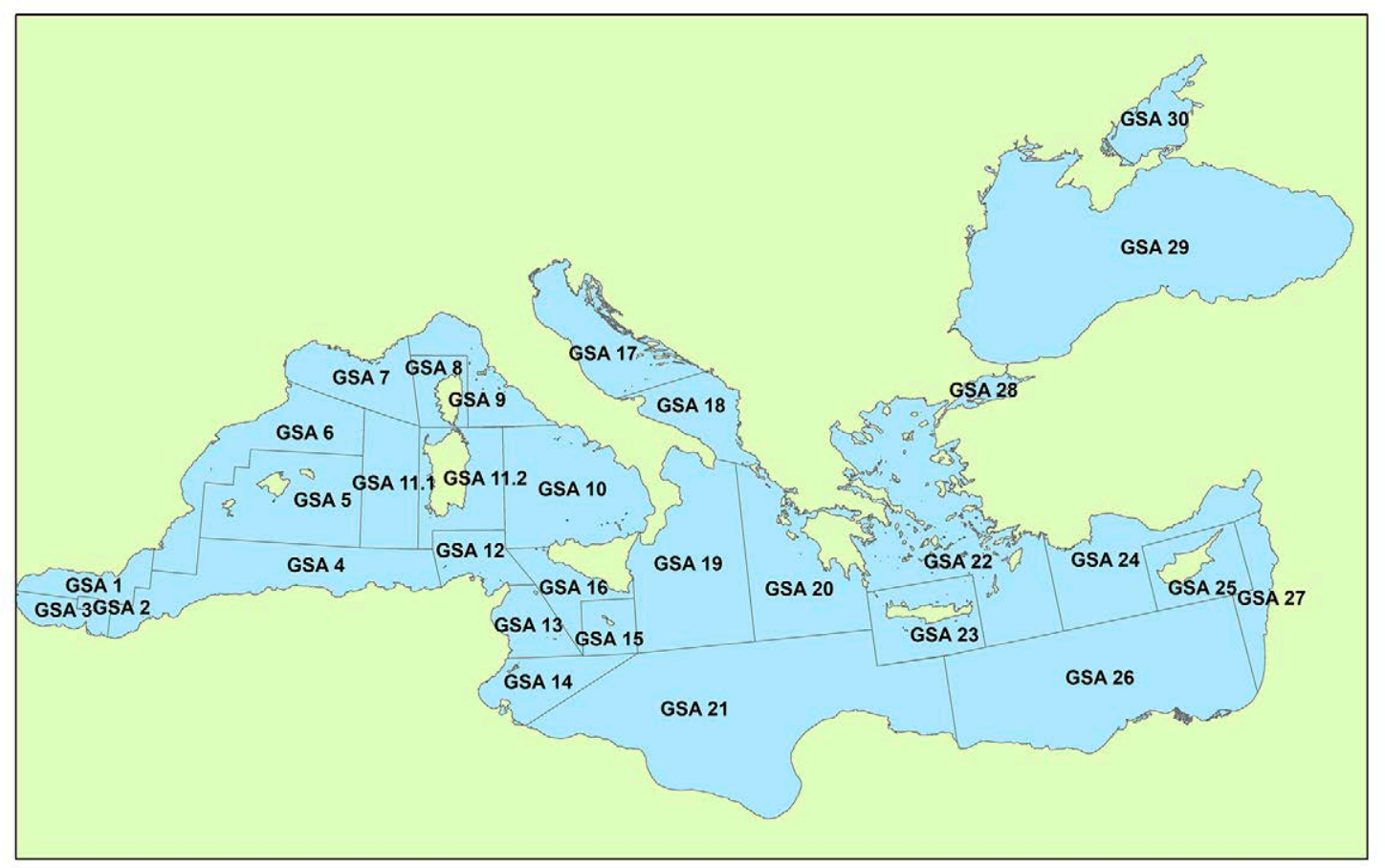

Fig. 1. - Geographical subareas (GSAs) in the General Fisheries Council for the Mediterranean (GFCM) area. The Mazara del Vallo trawlers operate in GSAs 12 to 16 (northern Tunisia; Gulf of Hammamet; Gulf of Gabes; Malta; southern Sicily) and 21 to 25 (southern Ionian Sea; Aegean Sea; Crete; northern Levant Sea; Cyprus). 
Table 1. - Trends in the fishing capacity of the trawl fleet $\geq 24 \mathrm{~m}$ of Mazara del Vallo. Source: MIPAAF data sourced from IREPA (2004 data) and ITAFISHSTAT (2016 data) from the official vessel register.

\begin{tabular}{ccc}
\hline Year & Number of vessels & Total kW \\
\hline 2004 & 137 & 59103 \\
2016 & 85 & 38429 \\
D $\%$ & $-38 \%$ & $-35 \%$ \\
\hline
\end{tabular}

Table 2. - Species composition of the trawl fleet in the Strait of Sicily. ARA, blue and red shrimp (Aristeus antennatus); ARS, giant red shrimp (Aristaemorpha foliacea); DPS, deepwater rose shrimp (Parapenaeus longirostris). Source: MIPAAF data sourced from IREPA (2004 data) and ITAFISHSTAT (2016 data).

\begin{tabular}{ccccc}
\hline & \multicolumn{2}{c}{ Landings weight } & \multicolumn{2}{c}{ Landings value } \\
Species & $\mathrm{t}$ & $\%$ & $€$ (thousands) & $\%$ \\
\hline 2004 & & & & \\
ARA & 182 & $1 \%$ & 2669 & $2 \%$ \\
ARS & 779 & $4 \%$ & 12416 & $9 \%$ \\
DPS & 6606 & $32 \%$ & 50458 & $37 \%$ \\
Other & 13234 & $64 \%$ & 70610 & $52 \%$ \\
Total & 20800 & $100 \%$ & 136152 & $100 \%$ \\
2016 & 402 & $3 \%$ & 9023 & $8 \%$ \\
ARA & 1490 & $11 \%$ & 33406 & $29 \%$ \\
ARS & 5293 & $40 \%$ & 32241 & $28 \%$ \\
DPS & 6169 & $46 \%$ & 39481 & $35 \%$ \\
Other & 13355 & $100 \%$ & 114150 & $100 \%$ \\
Total & & & & \\
\hline
\end{tabular}

In the last few years, together with this capacity reduction the traditional shallow-water fisheries that had mainly targeted fish and cephalopods has progressively changed into a more deep-water, shrimp-oriented fishery. In 2004, due to decreasing landings of ARA/ARS in the Strait of Sicily (GSA 16), some trawlers began to exploit fishing grounds in the eastern basin (Garofalo et al. 2007). From 2005, the number of vessels fishing in the eastern Mediterranean (GSA 20-25) also increased as a consequence of the extension of the Libyan fishery zone to 74 miles from the coastline. In 2016, about 20 trawlers targeting ARS/ARA were operating full-time in the eastern Mediterranean. The fishing trips lasted 2-3 months and every 20-30 days the catch frozen on board was landed on Crete, Rhodes or Cyprus and then shipped to Mazara del Vallo in refrigerated trucks and marketed throughout Italy.

The three shrimp species under analysis (DPS, ARS and ARA, in decreasing order of total landings) accounted for $48 \%$ of total landings for the Strait of Sicily in value in 2004 and $65 \%$ in 2016, and 37\% of total landings for this area in volume in 2004 and $54 \%$ in 2016 (Table 2). The production increased in volume by $121 \%$ for ARA and by $91 \%$ for ARS, and at the same time the prices increased by $53 \%$ and $41 \%$, respectively. Over the 13 -year period, the relative proportion of the three shrimp species changed from one-half to two-thirds of the total value of the catch for the trawl fleet. The frozen shrimp were sorted by quality groups and had a higher landed value than shrimp landed fresh. The Mazara del Vallo fleet is responsible for a large portion of the landings in the Strait of Sicily, with the three shrimp species landed by trawlers from Mazara amounting to more than $70 \%$ of the total value landed in the area in 2016.

\section{Measuring technical efficiency and scale efficiency using data envelopment analysis}

This study follows an input-oriented approach to analyse the TE and SE of demersal trawlers in Mazara del Vallo, where vessels may practice pesca a fresco and pesca a congelato strategies to different extents, depending on the vessel. As the managerial scheme in place is mainly input-based, and the two fishing strategies have different input utilization levels and therefore cost structures, the input-oriented DEA was deemed to be the most appropriate orientation to use. The DEA method was applied following two approaches: the approach developed by Charnes et al. (1978), in which TE is estimated under the assumption of constant returns to scale (CRS), and that suggested by Banker et al. (1984), in which the method was extended to include the cases of variable returns to scale (VRS).

Under CRS, vessels are assumed to operate at an optimal scale. This would mean, for instance, that a doubling of input would result in a doubling of output (Coelli et al. 2002). This is a rare occurrence in fisheries, where decreasing returns to scale are generally observed (Banker et al. 1984), owing to several factors including imperfect competition and financial limitations (Coelli et al. 2002). When returns to scale are not constant, the efficiency scores resulting under the CRS assumption are confounded by scale efficiencies. The VRS extension suggested by Banker et al. (1984) clearly allows for greater flexibility in the model. According to the scale of operation, VRS can be further distinguished into increasing returns to scale (IRS) and decreasing returns to scale (DRS). However, the CRS assumption is also applied in this study because comparing results under the two assumptions allows for an estimation of SE.

Considering N DMUs and, for each DMU, a vector of $\mathrm{M}$ outputs $y_{i}$ and a vector of $\mathrm{K}$ inputs $x_{i}$, under the CRS assumption, the TE for each DMU $\mathrm{j}$ is obtained by solving the following linear programming model:

$$
\begin{gathered}
\min _{\theta, \lambda} \theta \\
s t-y_{i}+Y \lambda \geq 0, \\
\theta x_{i}-Y \lambda \geq 0, \\
\lambda \geq 0
\end{gathered}
$$

where the $\mathrm{M} \times \mathrm{N}$ output matrix, $\mathrm{Y}$, and the $\mathrm{K} \times \mathrm{N}$ input matrix, $X$, contain the data of all N DMUs. The model is solved for each DMU in $\theta$ and $\lambda$, where $q$ is a scalar measure of the efficiency score of the DMU and $\lambda$ is an $\mathrm{N} \times 1$ vector of weighting factors. A value of 1 for $\theta$ indicates a point on the frontier and hence a technically efficient DMU. Values lower than 1 indicate technical inefficiency; the level of relative inefficiency is measured by $1-\theta$.

To account for VRS, the model formulation was modified by adding the constraint $N I^{\prime} \lambda=1$

$$
\begin{gathered}
\min _{\theta, \lambda} \theta \\
s t-y_{i}+Y \lambda \geq 0, \\
\theta x_{i}-Y \lambda \geq 0, \\
\lambda \geq 0 \\
N I^{\prime} \lambda=1
\end{gathered}
$$


where $N I$ is an $N \times 1$ vector of ones. The additional constraint allows for an estimation of efficiency scores without the effects of SE by making a comparison only between vessels of similar scale to one another. As data points are enveloped more tightly than under CRS and in a convex way, VRS efficiency scores will be greater than or equal to those estimated under CRS. The SE score is calculated as the ratio of TE score under CRS to TE score under VRS upon the same data.

Based on the approach proposed by Farrell (1957), inputs and outputs in Equations 1 and 2 should be expressed in physical quantities. However, as quantities are not always available, the use of values rather than quantities has become very common in the empirical studies on efficiency (e.g. Lindebo et al. 2007). In this study, we used values for both inputs and outputs. Following the approach suggested in Pinello et al. (2016), four variables are used as input in the DEA model: annual personnel cost, fuel cost, running cost and repair and maintenance cost. The output is the annual revenues of the vessels.

As suggested by Färe et al. (1990) and Banker et al. (2007), when prices are equal across DMUs, TE can be estimated by using values rather than quantities. Portela (2014) proved this equivalence and extended it to the case where input costs (or revenues) are aggregated into a single input. On the other hand, when prices are not equal across DMUs, TE can be incorrectly estimated. Under a profit maximization assumption, fishing strategies can be affected by the expected prices, the level of technology and the resource abundance (Squires 1987, Sharma and Leung 1998). The effects of different prices on the fishing strategies and therefore on the output level could erroneously be interpreted as variations in TE. However, as noted by Pinello et al. (2016), "the ability of fishers to respond to changes in relative prices by varying their fishing activity is limited". Changing the fishing gear at sea is generally not feasible and doing it on shore is quite time consuming. Furthermore, as suggested in Holland and Sutinen (2000), fishing activity is very dependent on habit and only limited variations are applied because of a change in prices. Therefore, the potential biases due to the use of values rather than quantities are not likely to be significant.

\section{Correlation with shrimp composition of the catch}

The TE scores estimated for each demersal trawler under the VRS specification were associated with the weight of the shrimp (DPS, ARA and ARS) in the landing composition. The percentage of shrimp landings out of the total landings weight was used as a proxy for the time spent conducting mid- and deep-water trawling operations. A correlation was tested between the presence of the deep-water shrimp species and the TE score. A positive correlation would indicate that pesca a congelato, targeting deep-water shrimps in the midand deep-water trawling, is more efficient than pesca a fresco, targeting other species in shallow water. The analysis was performed using a Spearman correlation.

\section{Data sources}

The analysis was based on data collected under the Italian National Programme, as well as through a focus group discussion with the trawler skippers, providing supplementary information to be integrated with the official data. Landings were compiled on an annual basis and the breakdown had to be based on the annual landings composition as the data were only available at this level of disaggregation. Vessels conducted two types of fishing strategy: pesca a congelato and pesca a fresco and some vessels adopted a mix of the two strategies. To best represent the two strategies plus the mixed strategies, three categories were created: pesca a congelato, in which the sum of deep-water shrimp (DPS, ARA and ARS) landings represented more than $80 \%$ of the annual revenue; pesca a fresco, in which deep-water shrimp represented less than $60 \%$ of the annual revenue; and the 'mixed strategy', in which the percentage of deep-water shrimp fell by $60 \%$ to $80 \%$ of the total value.

Primary economic data from a sample of 56 vessels, making up more than $50 \%$ of the fleet segment, were used. Data used in the analysis were collected on an annual basis through a multivariate sample survey, as described in the Italian National Programme for Data Collection (MIPAAF 2010). The data used herein were from 2004 and 2016 to compare the oldest available data with the most recent data. The core components of the survey (target population, stratification criteria and definition of variables) were prescribed by the EU Data Collection Framework (EU Commission 2010).

The sample unit was a single vessel selected from the vessel register. The sampling was conducted in a stratified manner so that the fishing vessels of the fleet were divided into homogenous groups based on the primary fishing technique, vessel length class and the geographical area of activity. The basic economic data

Table 3. - Descriptive statistics of the input and output variables used in the data envelopment analysis (DEA), $\mathrm{n}=56$ (total population, $\mathrm{N}=85$ ) (2016 data). The cost and revenue variables are presented for the three fishing strategies as mean values with the associated standard deviations. Source: MIPAAF data sourced from ITAFISHSTAT. Contribution of deep-water shrimp to annual revenue: $*>80 \%$; $* *<0 \%$; $* * * 60 \%-80 \%$

\begin{tabular}{|c|c|c|c|c|c|c|}
\hline & \multicolumn{2}{|c|}{ Pesca a congelato* } & \multicolumn{2}{|c|}{ Mixed-strategy*** } & \multicolumn{2}{|c|}{ Pesca a fresco $* *$} \\
\hline & Mean value $(€)$ & sd & Mean value (€) & sd & Mean value (€) & sd \\
\hline \multicolumn{7}{|l|}{ Input variables } \\
\hline Personnel cost & 215667 & 182929 & 158559 & 70985 & 140223 & 57424 \\
\hline Fuel cost & 123800 & 32732 & 115485 & 40801 & 107147 & 29026 \\
\hline Running cost & 51078 & 26902 & 37067 & 38712 & 49127 & 35221 \\
\hline Repair and maintenance cost & 45561 & 38400 & 55136 & 23862 & 59905 & 34352 \\
\hline \multicolumn{7}{|l|}{ Output variables } \\
\hline Revenues & 619837 & 404313 & 449599 & 185619 & 378036 & 181870 \\
\hline
\end{tabular}


Table 4. - Use of LED lights as collected in the focus group discussion.

\begin{tabular}{lcccccccc}
\hline & $\begin{array}{c}\text { Fishing } \\
\text { depth }\end{array}$ & $\begin{array}{c}\text { Duration of } \\
\text { the tow }\end{array}$ & $\begin{array}{c}\text { Crew } \\
\text { size }\end{array}$ & $\begin{array}{c}\text { Use of } \\
\text { lights }\end{array}$ & $\begin{array}{c}\text { Year } \\
\text { of first } \\
\text { use }\end{array}$ & $\begin{array}{c}\text { Colour prefe- } \\
\text { rence }\end{array}$ & $\begin{array}{c}\text { Number of } \\
\text { lights per } \\
\text { net }\end{array}$ & $\begin{array}{c}\text { Main problems re- } \\
\text { ported }\end{array}$ \\
\hline Pesca a fresco & $<250 \mathrm{~m}$ & $2-3$ & $8-9$ & no & n/a & n/a & n/a & Shortage of specialized \\
crew; \\
Pesca a congelato
\end{tabular}

were collected through a structured socio-economic questionnaire. The questionnaire included more than 70 micro-variables which allowed the variables used in the analysis to be estimated. Following the data collection, all the data were subjected to validation and control procedures.

The variables used for the DEA analysis consisted of four inputs, namely (i) personnel, (ii) fuel, (iii) running and (iv) repair and maintenance costs. The output was the annual revenues of the vessels (see Table 3 ).

Personnel costs refer to the compensation, in the form of pay, of all crew members, including the owner. The crew are paid on a share basis, which means that the greater the value of the catch landed, the more money each crew member gets as a share of the total. The share is usually calculated as a percentage of revenue, or revenue minus certain categories of cost. A minimum monthly salary is set through a national sector-specific contract (Contratto Collettivo Nazionale, $\mathrm{CCN}$ ), which includes social security and pension contributions. The crew share is calculated at the end of each fishing trip, and if the amount is less than the minimum monthly salary, then the $\mathrm{CCN}$ rate is paid.

Fuel costs refer to the total cost of the fuel consumed by all onboard vessel equipment (main engine, secondary engine, generators and machinery used on board). The running costs are all the purchased consumable inputs related directly or indirectly to fishing effort. Included are the inputs consumed within a fishing trip (e.g. food, lights and batteries for the lights) and the costs related to the sales of the products (e.g. ice and boxes). Repair and maintenance costs refer to both routine and extraordinary costs for the maintenance and repair of the vessel and gears.

\section{Data collected by the focus group}

Further data were collected during a focus group discussion conducted with the skippers of 23 vessels in the Mazara del Vallo trawl fleet in January 2017. The participants were selected as a sub-group of the total sample included in the case study of this work. Detailed information on the fishing strategies, employment on board, age of crew, literacy level and technical improvement in fishing nets for increasing fishing efficiency was investigated by the interviewers. Skippers were asked about the use of LED lights on the nets during trawling. Specifically, they were asked about the first year that the lights were used; the preferred light colour; and the number of lights attached per net, including their colour preference for the lights, which were ranked in order of preference. Furthermore, the skippers' perception of discard levels between the fish- ing strategies and the main problems encountered in the management of the activity were investigated.

\section{RESULTS}

Differences in fishing grounds of shallow and deepwater trawling were reflected in the differences in the crew size of the vessels as well as in the activity costs and the market modality. The pesca a fresco trawling was more labour-intensive (on average 8-9 crew per vessel) than the pesca a congelato (on average 6-7 crew per vessel). The pesca a fresco trawls had an average tow duration of approximately two hours with a tow speed of 3-4 knots, while the pesca a congelato had an average tow duration of four to five hours with a tow speed of 2-3 knots and a slower engine speed. These factors result in lower fuel consumption. Different crew sizes for the two strategies did not result in significant increases in personnel costs because under the crew-share system the proportion of revenues assigned to the crew-share is a fixed ratio, no matter the number of crew members (Gee et al. 2017, Pinello et al. 2017).

During a trawl operation, one of the most labourintensive components is the process of sorting the commercial catch from the discards. The reduced labour required for this activity with the pesca a congelato strategy is shown by the lower number of crew members required on these vessels and by evidence in the literature (e.g. Milisenda et al. 2017).

In Table 4 the main findings of the focus group discussion are reported. The discussion focused on eight main points, including the social component, the fishing activity and the use of the LED lights. Of the 23 individuals interviewed, more than $80 \%$ were owners who worked onboard their vessels as the skipper. Although demographic information such as age and educational levels were collected, no specific pattern related to this information was identified, so it was not reported here. When the focus group members were queried on the main problems related to the fishing activity, the majority of respondents highlighted the shortage of specialized crew, in particular skippers and engineers, and the need for more technological innovation aimed at further reducing discards and increasing the quality of the landings.

The pesca a congelato strategy showed the highest average levels of efficiency, with a TE of 0.96 and an SE of 0.99 (Table 5). In terms of TE, all of the pesca a congelato vessels were very close to the frontier and they were working at nearly the maximum level of efficiency. In fact, 15 vessels were found to be on the frontier of efficiency. The very high SE score highlighted 
Table 5. - Descriptive statistics of technical efficiency (TE), scale efficiency (SE) and scale of operation for pesca a congelato $(>80 \%)$. $\mathrm{N}=32$. IRS, increasing returns to scale; CRS, constant returns to scale; DRS, decreasing returns to scale.

\begin{tabular}{cccccc}
\hline Variable & Mean & sd & CV & Min. & Max. \\
\hline TE & 0.96 & 0.06 & $6.0 \%$ & 0.81 & 1.0 \\
SE & 0.99 & 0.02 & $2.1 \%$ & 0.93 & 1.0 \\
\hline \multicolumn{3}{c}{ Scale of operation } & \multicolumn{3}{c}{ DMUs } \\
\hline \multicolumn{3}{c}{ IRS } & \multicolumn{3}{c}{ 15 vessels (47\%) } \\
& CRS vessels (6\%) \\
& DRS & \multicolumn{3}{c}{15 vessels $(47 \%)$} \\
\hline
\end{tabular}

Table 6. - Descriptive statistics of technical efficiency (TE), scale efficiency (SE) and scale of operation for the mixed strategy $(60 \%-$ $80 \%$ ). $\mathrm{N}=16$. IRS, increasing returns to scale; CRS, constant returns to scale; DRS, decreasing returns to scale.

\begin{tabular}{cccccc}
\hline Variable & Mean & sd & CV & Min. & Max. \\
\hline TE & 0.91 & 0.08 & $9.2 \%$ & 0.70 & 1.0 \\
SE & 0.97 & 0.04 & $4.5 \%$ & 0.86 & 1.0 \\
\hline \multicolumn{3}{c}{ Scale of operation } & \multicolumn{3}{c}{ DMUs } \\
\hline & IRS & \multicolumn{3}{c}{ 13 vessels (81\%) } \\
& CRS & \multicolumn{3}{c}{ 0 vessels (19\%) } \\
DRS & \multicolumn{3}{c}{ vessels } \\
\hline
\end{tabular}

Table 7. - Descriptive statistics of technical efficiency (TE), scale efficiency (SE) and scale of operation for pesca a fresco $(<60 \%)$. $\mathrm{N}=8$. IRS, increasing returns to scale; CRS, constant returns to scale; DRS, decreasing returns to scale.

\begin{tabular}{|c|c|c|c|c|c|}
\hline Variable & Mean & sd & $\mathrm{CV}$ & Min. & Max. \\
\hline TE & 0.74 & 0.18 & $24.1 \%$ & 0.39 & 0.90 \\
\hline SE & 0.97 & 0.05 & $4.8 \%$ & 0.86 & 1.0 \\
\hline \multicolumn{3}{|c|}{ Scale of operation } & \multicolumn{3}{|c|}{ DMUs } \\
\hline \multicolumn{3}{|c|}{ IRS } & \multicolumn{3}{|c|}{7 vessels $(88 \%)$} \\
\hline \multicolumn{3}{|c|}{ CRS } & \multicolumn{3}{|c|}{1 vessels $(12 \%)$} \\
\hline \multicolumn{3}{|c|}{ DRS } & \multicolumn{3}{|c|}{0 vessels } \\
\hline
\end{tabular}

that the vessels were operating close to the optimal scale of production. On average, only one percent of inefficiency can be attributed to the scale size. CRS were detected for 2 vessels, while the remaining 30 vessels were equally distributed between those operating at IRS and those operating at DRS.

On average, the mixed strategy fell between the two other strategies, as measured by TE and SE (Table 6). The vessels following the mixed strategy had a TE level equal to 0.91 and there was only one vessel on the frontier, while the SE was 0.97. Three vessels were operating at CRS, while the other thirteen vessels were at IRS.

On average, the pesca a fresco was the less efficient fishing strategy, as measured by TE (Table 7). The vessels following this strategy had the lowest TE level, equal to 0.74 , and could therefore proportionally decrease their inputs by $36 \%$ and still produce the same amount of output. No vessels were on the frontier for the TE, while the SE was 0.97. IRS was found for seven vessels, while the optimal scale was detected for one vessel.

There is an evident positive correlation between the occurrence of shrimp in the landings and the higher efficiency scores found for the three categories of vessels (Table 8). The higher the presence of shrimp in
Table 8. - Spearman correlations of technical efficiency (TE) and scale efficiency (SE) scores of the three strategies with presence of crustaceans in the landings. ** 0.05 level of significance.

\begin{tabular}{lcc}
\hline & $\mathrm{TE}$ & $\mathrm{SE}$ \\
\hline Entire fleet & $0.70^{* *}$ & $0.31^{* *}$ \\
\hline
\end{tabular}

the landings, the higher the TE for the trawlers. The pesca a congelato showed the highest TE performance, with the greatest number of vessels on the frontier of efficiency while the pesca a fresco showed the lowest TE performance, with no vessels on the frontier of efficiency. The mixed-strategy vessels had a TE performance that was a mix of the two other categories and accordingly had no vessels on the frontier. The range of TE scores for the three categories corroborated the correlation between shrimp in landings and efficiency.

According to the focus group discussion, the fleet targeting shrimp started equipping their nets with LED lights in 2013. The fishers reported that the lights attract mainly ARA/ARS and DPS, therefore increasing the catchability of the gear, and seemed to be particularly effective at night. Although the effectiveness of the lights during daylight hours is probably lower because the shrimp would already be near the bottom, the fishers usually prefer to leave the lights operating. The preferred colours are white, green and blue, in that order, and the choice depends mostly on experiences gathered by fishers. In general, the trawl nets are equipped with about 100 flashing lights installed in groups of ten spaced two or three metres from each other. The LED lights are attached to the headrope of the net and to the bridles. They cost about $€ 3$ to $€ 5$ each, and to be kept constantly in operation they require two new batteries every 15 days, which cost about $€ 0.15$ each. The annual cost for the lights is therefore about $€ 300$ to $€ 500$ per net, while their maintenance costs are about $€ 20$ to $€ 30$ per fishing trip (20 days). Under the pesca a fresco strategy, the main targets were bony fish and cephalopods, which were landed fresh because the fishing trips lasted three days or less, with each tow lasting two hours or less. The short duration of the tow was an intentional strategy to reduce the total amount of catch in the cod end. Catches of unwanted species were a matter of concern to the fishers on two operational fronts. First, too high a quantity of catch in the codend increases the mechanical damage, which reduces the product quality; second, the sorting of the catch on the deck takes longer with higher quantities of non-targeted species. The vessels mainly operating under the a pesca a fresco strategy employed 8 to 9 fishers as a result of the increased workload due to more tows per fishing day and increased quantities of catch (landings plus discards) to handle. The pesca a congelato strategies targeting DPS $(250-400 \mathrm{~m})$ and ARA and ARS (>400 m) had fishing trips that lasted between one week and 20 days, and the catch was landed frozen. The tow lasted more than four hours at lower speeds as the lower amount of biomass allowed for a greater duration. The crews were smaller, with an average of 6 to 7 fishers because the smaller number of daily tows and the lower catch quantities reduce the required effort, while the lower speeds reduce the fuel 
consumption. The entry costs of using LED lights in the pesca a congelato strategy was so low $(<1 \%$ of the overall turnover) that the entire fleet has started to use them, and no correlation could be found with age of the skippers/owners who participated in the focus group discussions. Even fishers who were not convinced of the effectiveness of using the lights used them, just in case. Further, the fishers reported that they did not believe that the use of the lights during the daytime was effective, but the maintenance costs were so low and there did not seem to be any negative consequences of using the lights during daytime fishing, so the fishers left the lights on for all fishing activity. The use of lights has become a structural component of the gear, and it has become the latest technological innovation for this fleet.

\section{DISCUSSION}

Between the two main strategies followed by the Mazara del Vallo trawl fleet, pesca a congelato (at depths $>250 \mathrm{~m}$ ) showed higher TE and SE scores than pesca a fresco (at depths $<250 \mathrm{~m}$ ). Considering these positive efficiency performances, it would appear that the negative effects of overcapacity are not evident for the portion of the fleet which targets deep-water shrimp. Further, from the perspective of the DEA analysis, it would appear that the pesca a congelato fleet is close to a point of equilibrium, with a good balance between costs and revenue. Over the years, an increased use of LED lights has been found in the pesca a congelato fleet.

According to the fishers, the adoption of the use of LED lights has increased the catchability of the gear towards the deep-water shrimp, in particular during the night-time. For this reason, the use of lights extended the potential fishing time, and this allowed the fishing activity to become more specialized while further increasing its productivity rate. The adoption of the lights for the Mazara del Vallo fleet was done without any scientific inputs - the fishers adopted and spread this technological improvement within their own community. It has now spread across the entire fleet and has become a structural element of the fishery operations.

Further to the focus group discussion, it is well established that during the day shrimp feed mainly on detritus on the bottom while at night they migrate off the seafloor to predate on zooplankton (Shumway et al. 1985, Sobrino et al. 2005, Savenkoff et al. 2006). Light could lead shrimp to swim towards it, or, additionally, attract shrimp searching for prey towards the bottom, favouring their capture in the fishing gear.

Regarding the discard production, the focus group reported that there were reduced levels of discards in the pesca a congelato strategy, and this was further corroborated by the longer tow duration and lower crew sizes required for sorting the commercial catch from the discards (Table 4). This reporting was supported by findings in the literature, in which deep-water fishing resulted in lower discard levels. The available literature from the Mediterranean suggested that
Table 9. - Reported ranges of discards by depth category.

\begin{tabular}{lcl}
\hline Fishing depth & $\begin{array}{c}\text { Reported range of } \\
\text { discard (\%) }\end{array}$ & \multicolumn{1}{c}{ References } \\
\hline$<250 \mathrm{~m}$ & $43.2-90.4$ & $\begin{array}{l}\text { Sánchez et al. 2007, Sánchez } \\
\text { et al. 2004, Carbonell et al. } \\
\text { 2003, Pranovi et al. 2001 } \\
\text { Carbonell et al. 2003, } \\
\text { Castriota et al. 2001 }\end{array}$ \\
& $45.3-49$ & $\begin{array}{l}\text { Gorelli et al. 2016, } \\
\text { D'Onghia et al. 2003 }\end{array}$ \\
\hline
\end{tabular}

trawlers targeting deep-water crustaceans produced fewer discards than shallow-water trawlers. An average overall discard rate for bottom trawlers in the Strait of Sicily during the early 2000s was reported by Vitale et al. (2006) to be $52 \%$. For the shrimp fisheries of the Strait of Sicily, Castriota et al. (2001) reported a mean discarded biomass value of $49 \%$ of the total catches, similar to the discard ratio produced by other shrimp trawls in the Mediterranean Sea $(43.2 \% \pm 27.2 \%)$, but higher than mean values reported for other Mediterranean trawl fisheries $(32.9 \% \pm 2.8 \%)$ (Tsagarakis et al. 2013). More recently, Milisenda et al. (2017) analysed catches of bottom trawlers targeting deep-water rose shrimp (DPS) in the Strait of Sicily over the period 2009 to 2013, and reported a mean discard rate of $36 \%$ of the total catch. Finally, information reported in the review of Tsagarakis et al. (2013) suggested that there is a clear gradient of decreasing discard levels with increasing depths of fishing grounds and that deep-water $(>400 \mathrm{~m})$ trawling targeting shrimp generates fewer discards than shallow trawling that targets mid-water depths (Table 9).

The combination of these factors and the shortage of specialized crew has also had some influence on the shift of activities from the pesca a fresco towards the pesca a congelato strategy. The change of fishing strategy occurring in distant trawlers could have had a positive effect on discards. According to Gristina et al. (2013), the amount of immature individuals routinely discarded in demersal assemblages exploited by trawlers in the Strait of Sicily amounted to more than $60 \%$ at depths of less than $200 \mathrm{~m}$ and less than $30 \%$ at depths between 200 and $800 \mathrm{~m}$. Moving from shallow-water fisheries targeting fish and cephalopods to deep-water fisheries targeting crustaceans could be a good strategy for more sustainable trawling in the Mediterranean.

In summary, a clear correlation was found between the occurrence of shrimp in the landings and the higher efficiency scores of vessels with the pesca a congelato strategy. The lower levels of discards caught through pesca a congelato than pesca a fresco and the higher catchability of the gear through the regular utilization of lights can be considered further important points of reflection for the management of shared stocks exploited by trawling in the Mediterranean. Under an effective management framework, the evolution from classical multispecies fisheries targeting the shelf bottoms to a fishery targeting deep-water crustaceans on the slope could shift trawling in other Mediterranean fleets towards a more sustainable pattern from both an economic and from an ecological point of view. 


\section{ACKNOWLEDGEMENTS}

Dario Pinello, Paolo Accadia, Evelina Carmen Sabatella, Sergio Vitale and Fabio Fiorentino have received funding from the European Commission Horizon 2020 Research and Innovation Programme under Grant Agreement No. 634495 for the project Science, Technology, and Society Initiative to Minimize Unwanted Catches in European Fisheries (MINOUW). This publication reflects the views of the authors only and none of the funding parties can be held responsible for any use that may be made of the information contained herein.

\section{REFERENCES}

Banker R.D., Charnes A., Cooper W.W. 1984. Some models for estimating technical and scale inefficiencies in data envelopment analysis. Manage. Sci. 30: 1078-1092. https://doi.org/10.1287/mnsc.30.9.1078

Banker R.D., Chang H., Natarajan R. 2007. Estimating DEA technical and allocative inefficiency using aggregate cost or revenue data. J. Product. Anal. 27: 115-121. https://doi.org/10.1007/s11123-006-0027-1

Cochrane K.L. 2000. Reconciling sustainability, economic efficiency and equity in fisheries: the one that got away? Fish Fish. 1: 3-21. https://doi.org/10.1046/j.1467-2979.2000.00003.x

Carbonell A., Alemany F., Merella P., et al. 2003. The by-catch of sharks in the western Mediterranean (Balearic Islands) trawl fishery. Fish. Res. 61: 7-18. https://doi.org/10.1016/S0165-7836(02)00242-4

Castriota L., Campagnuolo S., Andaloro F. 2001. Shrimp trawl fishery by-catch in the Straits of Sicily (central Mediterranean Sea). Scientific Council Research Documents of the Northwest Atlantic Fisheries Organization, Serial No. N4501, No 01/113.

Charnes A., Cooper W.W., Rhodes E. 1978. Measuring the efficiency of decision making units. Eur. J. Oper. Res. 2: 429-444. https://doi.org/10.1016/0377-2217(78)90138-8

Coelli T.J., Grifell-Tatje E., Perelman S. 2002. Capacity utilisation and profitability: A decomposition of short-run profit efficiency. Int. J. Prod. Econ. 79: 261-278. https://doi.org/10.1016/S0925-5273(02)00236-0

Coelli T.J., Rao D.S.P., O’Donnell C.J., et al. 2005. An Introduction to Efficiency and Productivity Analysis, 2nd Edition. Springer, New York, 366 pp.

Colloca F., Cardinale M., Maynou F., et al. 2013. Rebuilding Mediterranean fisheries: a new paradigm for ecological sustainability. Fish Fish. 14: 89-109. https://doi.org/10.1111/j.1467-2979.2011.00453.x

Colloca F., Scarcella G., Libralato S. 2017. Recent Trends and Impacts of Fisheries Exploitation on Mediterranean Stocks and Ecosystems. Front. Mar. Sci. 4: 244. https://doi.org/10.3389/fmars.2017.00244

Dimech M., Kaiser M.J., Ragonese S., et al. 2012. Ecosystem effects of fishing on the continental slope in the Central Mediterranean Sea. Mar. Ecol. Prog. Ser. 449: 41-54. https://doi.org/10.3354/meps09475

Di Stefano G. 1989. Problematiche del trasporto del prodotto ittico di Mazara del Vallo. MSc thesis, Faculty of Economics, University of Palermo.

D’Onghia G., Carlucci R., Maiorano P., et al. 2003. Discards from deep-water bottom trawling in the eastern-central Mediterranean Sea and effects of mesh size changes. J. Northwest Atl. Fish. Soc. 31: 245-261. https://doi.org/10.2960/J.v31.a19

European Union (EU) Data Collection Framework (DCF). 2017. Regulation (EU) 2017/1004 of the European Parliament and of the Council on the establishment of a Union framework for the collection, management and use of data in the fisheries sector and support for scientific advice regarding the common fisheries policy and repealing Council Regulation (EC) No. 199/2008.

Färe R., Grosskopf S., Lee H. 1990. A nonparametric approach to expenditure-constrained profit maximization. Am. J. Agric. Econ. 72: 574-581. https://doi.org/10.2307/1243026

Farrell J.M. 1957. The Measurement of Productive Efficiency. J. R. Stat. Soc. 120: 253-290 https://doi.org/10.2307/2343100

Fiorentino F., Ben Meriem S., Bahri T., et al. 2008. Synthesis of information on some target species in the MedSudMed Project area (central Mediterranean). MedSudMed Tech. Doc. 15: 67 pp.

Fiorentino F., Ben Hadj Hamida O., Ben Meriem S., et al. 2013. Synthesis of information on some demersal crustaceans relevant for fisheries target species in the south-central Mediterranean Sea. MedSudMed Tech. Doc. 32: 120 pp.

Garofalo G., Giusto G.B., Cusumano S., et al. 2007. Sulla cattura per unità di sforzo della pesca a gamberi rossi sui fondi batiali del mediterraneo orientale. Biol. Mar. Medit. 14: 250-251.

Gee J., Pinello D., Polymeros K. 2017. Drivers of Labor-Related Indicators across Diverse Mediterranean Fisheries. Sustainability 9: 2000 . https://doi.org/10.3390/su9112000

Gorelli G., Blanco M., Sardà F., et al. 2016. Spatio-temporal variability of discards in the fishery of the deep-sea red shrimp Aristeus antennatus in the northwestern Mediterranean Sea: implications for management. Sci. Mar. 80: 79-88. https://doi.org/10.3989/scimar.04237.24A

Grafton R.Q., Kirkley J., Kompas T., et al. 2006. Economics for Fisheries Management. Ashgate Publishing Ltd., Aldershot, UK.

Gristina M., Bahri T., Fiorentino F., et al. 2006. Comparison of demersal fish assemblages in three areas of the Strait of Sicily under different trawling pressure. Fish. Res. 81: 60-71. https://doi.org/10.1016/j.fishres.2006.05.010

Gristina M., Fiorentino F., Gancitano V., et al. 2013. The role of juveniles in structuring demersal assemblages in trawled fishing grounds. Est. Coast. Shelf Sci. 133: 78-87. https://doi.org/10.1016/j.ecss.2013.08.014

Holland D.S., Sutinen J.G. 2000. Location choice in New England trawl fisheries: Old habits die hard. Land. Econ. 76: 133-149. https://doi.org/10.2307/3147262

Idda L., Madau F.A., Pulina P. 2009. Capacity and economic efficiency in small-scale fisheries: evidence from the Mediterranean Sea. Mar. Policy 33: 860-867. https://doi.org/10.1016/j.marpol.2009.03.006

Kirkley J., Paul C.J.M., Squires D. 2002. Capacity and capacity utilization in common-pool resource industries. Environ. Resour. Econ. 22: 71-97. https://doi.org/10.1023/A:1015511232039

Kirkley J., Paul C.J.M., Cunningham S. et al. 2004. Embodied and disembodied technical change in fisheries: an analysis of the Sète trawl fishery, 1985-1999. Environ. Resour. Econ. 29: 191-217. https://doi.org/10.1023/B:EARE.0000044603.62123.1d

Knittweiss L., Arneri E., Ben Meriem S., et al. 2013. Stock status and potential yield of deep water rose shrimp (Parapenaeus longirostris, Lucas 1846) in the south-central Mediterranean Sea. MedSudMed Tech. Doc. 28: 15 pp.

Kumbhakar S.C., Lovell C.A.K. 2000. Stochastic Frontier Analysis. Cambridge University Press, Cambridge, UK. https://doi.org/10.1017/CBO9781139174411

Lindebo E., Hoff A., Vestergaard N. 2007. Revenue-based capacity utilisation measures and decomposition: The case of Danish North Sea trawlers. Eur. J. Oper. Res. 180: 215-227. https://doi.org/10.1016/j.ejor.2006.03.050

Maravelias C.D., Tsitsika E.V. 2008. Economic efficiency analysis and fleet capacity assessment in Mediterranean fisheries. Fish. Res. 93: 85-91. https://doi.org/10.1016/j.fishres.2008.02.013

Milisenda G., Vitale S., Massi D., et al. 2017. Discard composition associated with the deep water rose shrimp fisheries (Parapenaeus longirostris, Lucas 1846) in the south-central Mediterranean Sea. Med. Mar. Sci. 18: 53-63. https://doi.org/10.12681/mms.1787

Ministero delle Politiche Agricole e Forestali (MIPAAF). 2010. Italian National Program under Council Regulation (EC) n 199/08 and Commission Regulation (EC) n. 665/2008 - Annex I: Methodology for the estimation of economic variables.

Pascoe S., Coglan L. 2002. Contribution of unmeasurable factors to the efficiency of fishing vessels. Am. J. Agric. Econ. 84: 45-57. https://doi.org/10.1111/1467-8276.00321

Pascoe S., Andersen J.L., deWilde J.W. 2001. The impact of management regulation on the technical efficiency of vessels in the 
Dutch beam trawl fishery. Eur. Rev. Agric. Econ. 28: 187-206. https://doi.org/10.1093/erae/28.2.187

Pascoe S., Kirkley J.E., Greboval D.F., et al. 2003. Measuring and Assessing Capacity in Fisheries: Issues and Methods. FAO Fish. Tech. Pap. No. 433/2. Rome, FAO, 130 pp.

Pinello D., Liontakis A., Sintori A., et al. 2016. Assessing the Efficiency of Small-Scale and Bottom Trawler Vessels in Greece. Sustainability 8: 681 . https://doi.org/10.3390/su8070681

Pinello D., Gee J., Polymeros K. 2017. An unconventional approach to estimating crew remuneration in fisheries. Mar. Policy 87: 226-233.

https://doi.org/10.1016/j.marpol.2017.08.031

Portela M.C.A.S. 2014. Value and quantity data in economic and technical efficiency measurement. Econ. Lett. 124: 108-112. https://doi.org/10.1016/j.econlet.2014.04.023

Pranovi F., Raicevich S., Franceschini G., et al. 2001. Discard analysis and damage to non-target species in the "rapido" trawl fishery. Mar. Biol. 139: 863-875. https://doi.org/10.1007/s002270100646

Reid C., Squires D., Jeon Y., et al. 2003. An analysis of fishing capacity in the western and central Pacific Ocean tuna fishery and management implications. Mar. Policy 27: 449-469. https://doi.org/10.1016/S0308-597X(03)00065-4

Sánchez P., Demestre M., Martín P. 2004. Characterization of the discards generated by bottom trawling in the northwestern Mediterranean. Fish. Res. 67: 71-80. https://doi.org/10.1016/j.fishres.2003.08.004

Sánchez P., Sartor P., Recasens L., et al. 2007. Trawl catch composition during different fishing intensity periods in two Mediterranean demersal fishing grounds. Sci. Mar. 71: 765-773. https://doi.org/10.3989/scimar.2007.71n4765

Savenkoff C., Savard L., Morin B., et al. 2006. Main prey and predators of northern shrimp (Pandalus borealis) in the northern Gulf of St. Lawrence during the mid-1980s, mid-1990s, and early 2000s. Can. Tech. Rep. Fish. Aqua. Sci. 2639, 28 pp.

Sharma K.R., Leung P. 1998. Technical efficiency of the longline fishery in Hawaii: An application of a stochastic production frontier. Mar. Resour. Econ. 13: 259-274. https://doi.org/10.1086/mre.13.4.42629241

Shumway S.E., Perkins H.C., Schick D.F., et al. 1985. Synopsis of biological data on the pink shrimp, Pandalus borealis Krøyer, 1838. FAO Fish Synop. 144 pp.
Sobrino I., Silva C., Sbrana M., et al. 2005. A review of the biology and fisheries of the deep water rose shrimp, Parapenaeus longirostris, in European Atlantic and Mediterranean waters (Decapoda, Dendrobranchiata, Penaeidae). Crustaceana, 78: 1153-1184. https://doi.org/10.1163/156854005775903564

Squires D. 1987. Public regulation and the structure of production in multiproduct industries: an application to the New England otter trawl industry. Rand. J. Econ. 18: 232-247.

Squires D., Kirkley J. 1999. Skipper skill and panel data in fishing industries. Can. J. Fish. Aquat. Sci. 56: 2011-2018. https://doi.org/10.1139/f99-135

Tingley D., Pascoe S., Coglan L. 2005. Factors affecting technical efficiency in fisheries: stochastic production frontier versus data envelopment analysis approaches. Fish. Res. 73: 363-376. https://doi.org/10.1016/j.fishres.2005.01.008

Tsagarakis K., Palialexis A., Vassilopoulou V. 2013. Mediterranean fishery discards: review of the existing knowledge. ICES J. Mar. Sci. 71: 1219-1234. https://doi.org/10.1093/icesjms/fst074

Vázquez-Rowe I., Tyedmers P. 2013. Identifying the importance of the "skipper effect" within sources of measured inefficiency in fisheries through data envelopment analysis (DEA). Mar. Policy 38: 387-396. https://doi.org/10.1016/j.marpol.2012.06.018

Vestergaard N., Squires D., Kirkley J. 2003. Measuring capacity and capacity utilization in fisheries: The case of the Danish Gillnet fleet. Fish. Res. 60: 357-368. https://doi.org/10.1016/S0165-7836(02)00141-8

Villasante S. 2010. Global assessment of the European fishing fleet: an update. Mar. Policy 34: 663-670. https://doi.org/10.1016/j.marpol.2009.12.007

Villasante S., Sumaila U.R. 2010. Estimating the effects of technological efficiency on the European fishing fleet. Mar. Policy 34: $720-722$. https://doi.org/10.1016/j.marpol.2009.11.008

Vitale S., Cannizzaro L., Bono G., et al. 2006. Catch composition of Decapod Crustaceans from Trawl fishery catches in the Central Mediterranean Sea. J. Coast. Res. 39: 1798-1800.

Ward J.M., Kirkley J.E., Metzner R., et al. 2004. Measuring and assessing capacity in fisheries. 1. Basic concepts and management options. FAO Fish. Tech. Pap. 433/1. Rome, FAO. 40 pp. 